\title{
Проблемы развития микроэлектроники КНР и Тайваня
}

Тайвань долгие годы в качестве одного из "азиатских тигров" (наравне с Гонконгом, Сингапуром и Ю. Кореей являлся "новой индустриальной страной") играл значительную роль в мировой микро- и радиоэлектроники. Однако по мере реализации экономических преобразований в КНР положение этих стран стало осложняться - сказывается разность экономических и других потенциалов. Гонконг стал частью КНР, а Сингапур фактически отказался от собственной микроэлектроники из-за растущей стоимости современных полупроводниковых предприятий. Тайваньские фирмы, активно осваивавшие рынок КНР и открывавшие в "Поднебесной" свои филиалы, сегодня сталкиваются с растущей конкурентоспособностью китайских фирм и давлением властей и вынуждены возвращаться на остров. КНР же продолжает реализовывать амбициозные планы по достижению самообеспеченности современной ЭКБ, наращивает производство микро- и радиоэлектроники.

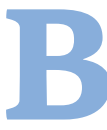

начале апреля в КНР прошел саммит руководителей китайских микроэлектронных фирм различных форм собственности. В его рамках был проведен форум «Обратный отсчет: насколько далек Китай от реализации планов обеспечения самодостаточности в области ИС порядка 40\%?» Мероприятие было организовано изданиями EE Times China, EDN China и ESM China Electronic Business, входящими в издательскийхолдинг AspenCore.

В 2015 году государственный совет КНР принял план «Сделано в Китае - 2025», в котором были поставлены следующие цели:

- достижение самообеспеченности производства ИС в 2020 году на уровне 40\%;

- увеличение уровня самообеспеченности до 70\% в 2025 году [1, 2].

Надо отметить, что план "Сделано в Китае-2025» охватывает не только микроэлектронику, а еще десять "стратегических" направлений развития страны, при этом собственно микроэлектроника является составной частью направления «Информационные технологии» (рис. 1). Кроме того, аспекты разработки и использования изделий микроэлектроники в большей или меньшей мере затрагиваются во всех стратегических направлениях - ввиду того, что они являются неотъемлемой частью современных систем управления, основой создания любых электронных систем.

Цнии «Электроника», главный специалист,

mmackushin@gmail.com.

Цнии «Электроника», генеральный директор
Однако спустя три года после анонсирования амбициозных планов ситуация практически не изменилась. В соответствии с данными Главного таможенного управления КНР, общий объем импортированных ИС составил 417,57 млрд шт. в натуральном выражении и 312 млрд долл. в стоимостном исчислении. Отмечаются два момента: во-первых, китайский импорт ИС впервые превысил 300 млрд долл.; во-вторых, прирост импорта ИС в 2018 году по сравнению с 2017-м составил 19,8\%.

Основные проблемы китайской микроэлектроники можно определить следующим образом:

- не установлены рынки, которые надо завоевать в первую очередь;

- в стране ощущается недостаток внутренних разработок в области интеллектуальной собственности по базовым изделиям;

- не развита национальная инфраструктура инструментальных средств САПр;

- констатируется недостаточное развитие производства промышленного оборудования.

Без решения этих вопросов задачи обеспечения самодостаточности в области производства ИС решены не будут.

\section{ОБРАТНЫЙ ОТСЧЕТ: НАСКОЛЬКО КИТАЙ ПРИБЛИЗИЛСЯ К САМООБЕСПЕЧЕНИЮ ИС НА УРОВНЕ $40 \%$ ?} КНР, по утверждениям представителей местной микроэлектроники, становится все более независимым от зарубежных поставок. Тем не менее, по-прежнему требуется постановка конкретных промежуточных целей и их приоритезация. 


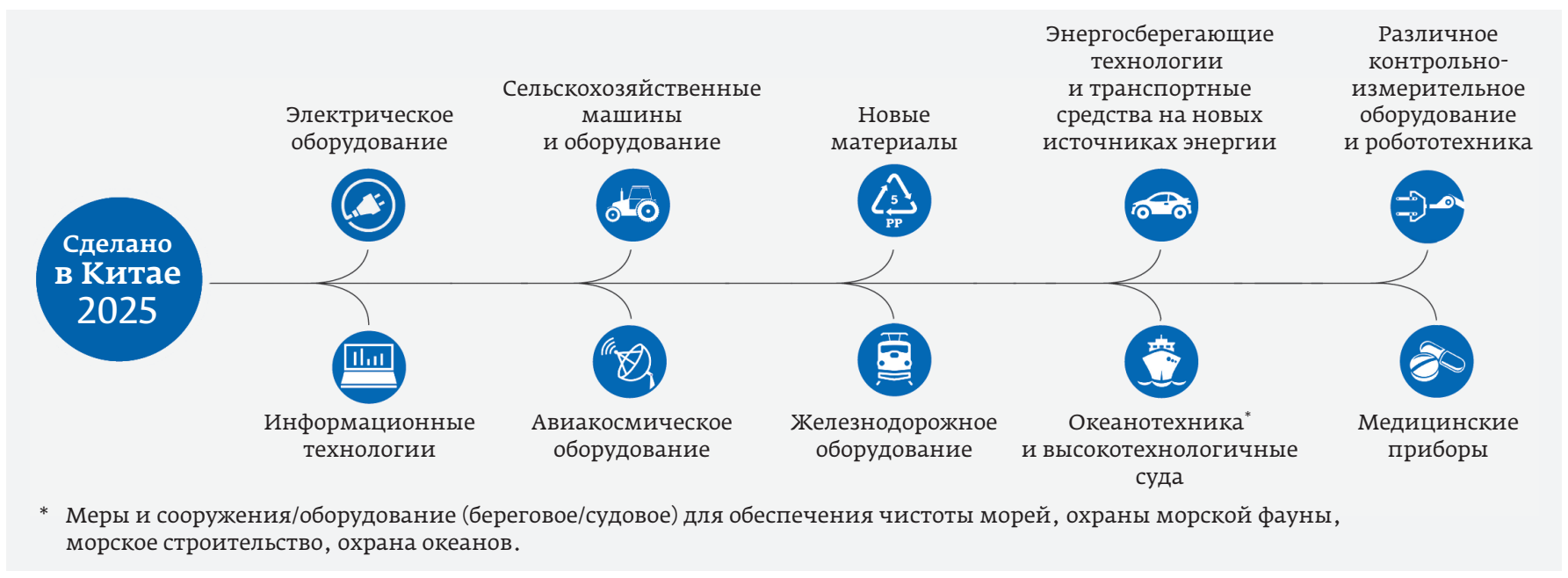

Рис. 1. Основные направления технологических прорывов в соответствии с планом "Сделано в Китае - 2025". Источник: https://static.tildacdn.com/tild3734-3037-4331-b632-663734653830/china2025.png

Участники форума "Обратный отсчет:..." высказались о задачах, стоящих в связи с целями развития внутренней микроэлектроники.

Остро стоит вопрос уточнения целей дальнейшего развития индустрии приборов памяти, где китайские фирмы, с одной стороны, добились успехов, а, с другой стороны, часто мешают друг другу - нет должной координации действий.

Одной из следующих задач становится выход на рынок микроконтроллеров, емкость которого в 2018 году достигла 20 млрд долл. Он, по-прежнему, контролируется американскими фирмами, несмотря на то, что значительная часть этихприборов изготавливается на китайских кремниевыхзаводах по спецификациям американских разработчиков.

Участники форума неоднократно подчеркивали, что задача самообеспечения КНР средствами микроэлектроники примерно на 40\% зависит от финансирования перспективных разработок. Один из путей - прямая закупка иностранных перспективных технологий, но в связи с вводимыми США и их союзниками ограничениями (на инвестиции в разработки иностранными, прежде всего китайскими фирмами) этот способ становится для развивающихся стран все более проблематичным.

Китайские специалисты определяют самой важной целью накопление базовых навыков. При этом если проекты проводятся с государственным участием, частным фирмам важно конкретнее формулировать собственные цели.

\section{Позиция производителей}

Выступавшие на конференции представители микроэлектронных фирм КНР отмечали, что уровень в 40\% более относится к требованию правительства страны - как ориентира. Однако у каждой фирмы вполне могут быть собственные установки, формулировка которых зависит от корпоративных планов развития и степени вовлеченности в государственные программы. Соответственно, доля самообеспечения может начинаться с 0-10\% и доходить до 60\%. Главное - повышение конкурентоспособности.

Было отмечено, что среди 14 крупнейших изготовителей ИС, сертифицированных ZigBee" Alliance, только одна фирма является китайской. Тем не менее в области телекоммуникаций китайские производители ИС добились больших успехов. Представители Шанхайской ассоциации микроэлектроники (Shanghai Integrated Circuit Industry Association, SICA) и корпорации Shanghai $\mathrm{HH}$ Grace Semiconductor Manufacturing отметили, что для ускорения процесса самообеспечения Ис отечественного производства необходимо укрепление сотрудничества между китайскими изготовителями ИС и производителями конечных электронных систем. Цепочка поставок ИС очень длинная - от проектировщиков до производителей, поставщиков услуг корпусирования, а также средств тестирования и материалов. Сейчас в мире нет ни одной страны, которая могла бы доминировать в сфере как разработки, так и производства микроэлектроники. Цель Китая - создать целостную промышленную цепочку в полностью закрытой среде. Строительство современных заводов по обработке полупроводниковых пластин (в первую очередь кремниевых заводов) значительно активизировалось в 2014 году, поэтому, как ожидается, уровень локализации производства ИС к 2020 году существенно вырастет.

* ZigBee - патентованный набор коммуникационных протоколов высокого уровня, разработанный для использования маленьких цифровых радиоустройств с низкой потребляемой мощностью на базе стандарта IEEE802.15.4 для беспроводных личных (персональных) сетей 


\section{ПРЕДЛАГАЕМЫЕ РЕШЕНИЯ}

Для китайских фирм возможностью конкурировать с иностранными производителями могут стать "ничейные земли", то есть новые рынки с несформировавшейся структурой и не выявившимися лидерами. К таким областям относятся искусственный интеллект и автономные транспортные средства - здесь отраслевые стандарты находятся в зачаточном состоянии. Не сможет ли китайская микроэлектроника воспользоваться этим шансом для разработки и утверждения на мировом уровне собственной архитектуры Ис и соответствующей технологической экосистемы?

Возможно, есть смысл попробовать силы на «побочных» рынках, таких как смарт-аудиоприборы и беспроводные наушники (которые также могут использоваться в качестве слуховых аппаратов). Эти новые изделия пока не получили широкого распространения, но обладают хорошими рыночными перспективами - с точки зрения наращивания продаж в натуральном выражении (с последующим выходом на прирост продаж в стоимостном выражении)

Также ряд экспертов отметил, что в наступающей "пост-Муровской»" эпохе развития микро- и радиоэлектроники именно прикладные применения могут стать движущим фактором китайской промышленности. КНР может использовать свой огромный внутренний рынок как средство установления / формирования мировых тенденций и стандартов.

К перспективным направлениям развития микро-и радиоэлектроники относятся "умные» города и сфера здравоохранения. Страна с таким большим населением как Китай не может не использовать такие перспективные рыночные факторы, как численность населения, в том числе платежеспособного. Более того, значительная часть спроса на перспективные рынки определяется формируемыми системными требованиями (а потом и стандартами) к новым видам техники. Китаю, как одному из ведущих производителей электроники, выпадает возможность навязывать миру свои стандарты. Например, в области Интернета вещей очень устойчивые позиции завоевала корпорация Huawei. При этом, как только формируется определенный стандарт, у китайских фирм появляются хорошие шансы достичь мирового лидерства - особенно в области бытовой техники, средств управления производственными процессами и Интернета вещей. В области человеко-машинного

* Moore's Law - так называемый закон Мура - эмпирическое наблюдение, а не природный (физический) закон - удвоение числа транзисторов на кристалле каждые 18 месяцев без увеличения удельной стоимости функций для конечного потребителя. Сформулировано в конце 70-х годов XX века Гордоном Муром, одним из основателей и ведущих специалистов корпорации Intel. взаимодействия быстро растет роль таких китайских фирм, как Haier, Midea и Gree (последняя становится лидером в области бытовой техники).

На конференции было отмечено, что китайским производителям электронных систем и домашнего оборудования необходимо укреплять взаимодействие с производителями ИС с целью оптимизации систем. Имеются в виду улучшение системной интеграции и снижение издержек. В этом плане китайские фирмы в последнее время смогли достичь ведущих позиций в мире. Более того, они фактически устанавливают новые стандарты - вопрос в том, будет ли это касаться только Китая или всего мира.

Вопрос стандартизации занимает отдельное место в китайской микро- и радиоэлектронике. Исторически сложилось так, что центральное китайское правительство участвовало в официальной деятельности по стандартизации только в сфере ИС. Однако цепочка поставок телекоммуникационного оборудования не только длиннее - она более рассредоточена. Следовательно, на отраслевое развитие могут влиять отдельные корпоративные стандарты.

Однако односторонние действия не приводят к автоматическому лидерству на рынке. Если другие ведущие производители не согласятся с "первопроходцем", то даже хорошие технические условия могут не стать отраслевым стандартом. Итог будет определяться рыночной конкуренцией

В настоящее время относительно широкое распространение получил тензорный процессорный блок (tensor processing unit, TPU) корпорации Google. Мало кто сомневается в ее возможности лидировать на рынке. Но в то же время небольшая фирма, предлагающая инновационный продукт, может оказаться не в состоянии его реализовать. Это обусловлено тем, что изделие не соответствует заявленным характеристикам, и тем, что у небольшой фирмы может просто не хватить ресурсов на раскрытие инновационного потенциала ее разработки.

На конференции было отмечено также, что при формировании китайских стандартов их необходимо приводить в соответствие с тенденциями международного развития. Никто в мире не верит, что китайские производители в течение ближайших 10 лет победят Apple или Google, но к этому надо стремиться - в соответствии с китайскими пятилетними планами.

\section{СТАНДАРТИЗАЦИЯ: МЕЖДУНАРОДНЫЕ И НАЦИОНАЛЬНЫЕ АСПЕКТЫ}

Цель приведения местных стандартов в соответствие с международными аналогами, возможно, не является вполне правильной. С другой стороны, курс на национальную автономию не всегда является наиболее эффективной стратегией в контексте глобализации. В закрытых системах страна или предприятие могут создать 
свой стандарт, но его действие может ограничиться национальной территорией, причем не всей.

Таким образом, ставится цель сотрудничества китайских и международных фирм для продвижения собственных стандартов и / или обеспечения прав своей интеллектуальной собственности

\section{Постановка задачи}

Если китайские фирмы могут достичь лидерства в определенной области, то они должны смело сотрудничать с международными (многонациональными) компаниями или создавать бизнес-альянсы для установления стандартов и последующего формирования отношений, позволяющих поглотить перспективные фирмы.

особое место в планах китайских микроэлектронных фирм занимают вопросы искусственного интеллекта. На саммите руководителей этих фирм было высказано мнение, что искусственный интеллект - просто технология, которая может использоваться в различных ИС и электронных системах. Эта технология наиболее широко применяется в Китае, но только за счет большей емкости внутреннего рынка. О превосходстве КНР над США в области новейших разработок, касающихся искусственного интеллекта, речи пока не идет.

Большой рынок потребительской электроники Китая позволяет обеспечить относительно быстрое совершенствование алгоритмов искусственного интеллекта и конструкций ИС. Это создает синергетическую ситуацию, которая способствует управлению развитием рынка средств искусственного интеллекта.

Правда, китайские производители микроэлектроники, по-прежнему, догоняют лидеров рынка. Исключением в этой практике можно считать корпорацию Huawei и ряд других крупных фирм. В этой связи особые надежды возлагаются на развитие национального кадрового потенциала отрасли - от школьных программ "привлечения внимания" до углубленных университетских курсов.

\section{Неизбежные проблемы}

Основное поле битвы в области ИС - не сокращающийся спрос на них со стороны изготовителей электронной техники. Особенно высоким спросом пользуются процессоры общего назначения и аналоговые приборы. Главный вопрос конкуренции между китайскими и иностранными производителями сводится к сохранению прав интеллектуальной собственности. Обвиняемой стороной, как правило, выступает Китай. Хотя в стране разработано несколько перспективных типов ИС, «Поднебесная» по-прежнему сильно отстает от международных конкурентов.

Правда, случаются и обратные ситуации: в некоторых областях, например, в транскодировании видео в облачных средах и сетевых ИС, Китай сумел опередить американские фирмы. Китайские производители создали схемы, которые при значительно меньшей потребляемой мощности (1/30), обеспечивают кодирование/декодирование на сопоставимом уровне. После этого ряд западных корпораций запросил лицензии на китайские разработки.

То, что, по мнению западных аналитиков, дает китайцам преимущества - создание на государственные (пятилетние планы, планы развития провинций и / или крупных городов) и частные средства кластеров, обеспечивающих концентрированное и эффективное создание кадрового потенциала отрасли.

\section{РАЗВИТИЕ ИНДУСТРИИ САПР}

Фактически интеллектуальную собственность и смежные права на территории КНР в области инструментальных средств САПР на 95\% контролируют иностранные фирмы. Крупнейшим разработчиком китайских САПР является фирма Empyrean Software, созданная около 10 лет назад. При этом возраст мировой индустрии САПР - около 60 лет. Китаю предстоит преодолеть создавшийся разрыв.

Одним из способов исправления сложившейся ситуации является активизация местных разработчиков САПР и контрактных производителей электроники (ОЕМ). Пример - сотрудничество Empyrean и Huawei. Правда, пока китайские фирмы предпочитают закупать американские средства САПР - более простые и отработанные в использовании. Для повышения конкурентоспособности китайских поставщиков САПР предлагаются взаимоисключающие подходы - государственная поддержка и отказ от нее в пользу сотрудничества с известными западными фирмами.

По оценкам, китайская индустрия САПР сможет сравняться с зарубежными конкурентами в течение 10-20 лет [3].

\section{БЕГСТВО ТАЙВАНЬСКИХ ФИРМ ИЗ КНР}

Тайваньские высокотехнологичные фирмы долго рвались на китайский рынок, боролись за право работать там со своим правительством, вводившим для них ограничения. Они уже вложили в свои заводы на территории КНР значительные средства, а теперь уходят... Правда, как говорят обозреватели, это не столько о Трампе, сколько о Си Цзиньпине.

Множество тайваньских фирм, переместивших свои производственные операции в Китай за последние десятилетия, теперь возвращаются домой. За четыре месяца 40 островных фирм со значительным объемом бизнеса в КНР решили покинуть материк. Это движение, иногда описываемое на Тайване как “ход лосося» (на нерест), вряд ли можно назвать исходом. Тем не менее это веха для Тайваня, правительство которого более пятнадцати лет пытается выманить эти фирмы из Китая. 
По данным Министерства экономики (Ministry of Economic Affairs, MOEA) страны, фирмы, объявившие об уходе из КНР, пообещали правительству в Тайбэе инвестировать на родине более 200 млрд тайваньских долларов (6,47 млрд долл. США). Как надеется министерство, число "репатриантов" увеличится. Обозреватели же полагают, что уже вернулось больше фирм, чем объявляло о подобном решении - потихоньку, без фанфар. Для Тайваня даже эта сумма инвестиций будет значительной из-за того, что остров не обладает требуемыми финансовыми ресурсами. Положение осложняется тем, что в ближайшие годы КНР планирует вложить в развитие своей микроэлектроники более 100 млрд долл., и позиции тайваньских фирм будут ухудшаться и далее.

Наиболее распространенным считается мнение, что данное явление спровоцировала американо-китайская торговая война. Запретительные ставки таможенных тарифов, введенные правительством США на китайские промышленные товары, поставили фирмы, обладающие мощностями в КНР, перед лицом потери доходов.

Однако, по словам некоторых высокопоставленных руководителей фирм и тайбэйских официальных лиц, для производителей, уже планировавших покинуть КНР, это просто оказалось удобной ширмой. На самом деле тайванцы уже давно видели зловещие предзнаменования, и краткосрочная политическая напряженность между двумя мировыми экономическими гигантами просто удобный предлог. Реальными причинами возвращения тайваньского хайтека на родину является ухудшение условий бизнеса". К ним относится рост стоимости рабочей силы, бремя оплаты быстро растущих расходов на социальное обеспечение и экологические налоги. Для крупных корпораций, таких как Foxconn, это не очень существенная проблема. Но большинство малых и средних тайваньских фирм не может удовлетворить постоянно ужесточающиеся требования китайцев. Наконец, не в последнюю очередь, Тайвань обеспокоен растущими политическими и экономическими страхами перед гигантским соседом. Например, многие тайваньские бизнесмены находят систему социальных кредитов КНР, в рамках которой правительство ранжирует собственных граждан (включая их активность в Интернете), особенно раздражающей.

\section{Формирование более полной цепи поставок}

Обращение вспять инвестиционного потока служит огромным стимулом для увеличения уверенности в себе как народа, так и правительства Тайваня.

Business environment - условия (внешняя среда) бизнеса, любые внешние по отношению к фирме факторы, прямо или косвенно влияющие на ее деятельность: предложение сырья, спрос на продукцию, налоговое законодательство и т.п.
Возвращающиеся домой фирмы являются лидерами местной промышленности.

На проходившей в середине апреля текущего года Тайбэйской международной выставке автомобильных узлов и принадлежностей (Taipei International Auto Parts \& Accessories Show) руководители местных промышленных ассоциаций и представителей правительства рассмотрели тему репатриации на примере той же автомобильной промышленности. В числе последних "возвращенцев" оказались фирмы Sonar Auto (специализация - настройка автомобильной светотехники) и Mobiletron Electronics (специализация - системы управления аккумуляторными батареями). Предполагается, что инвестиции этих фирм позволят создать на острове гораздо более комплексную цепочку поставок. Так, Mobiletron приняла решение об инвестировании около 2,5 млрд тайваньских долларов (81 млн долл.) в свои производства близ Тайчжуна (центр западного Тайваня) в III кв. 2019 года, а производство электрических шин (для систем управления аккумуляторами) начнется ближе к концу года.

На выставке было подчеркнуто, что страна снова становится центром производства подключаемых (к сетям) автомобилей и перспективных систем помощи водителю (ADAS).

\section{Стоимость ведения бизнеса в Китае для тайваньских предпринимателей}

Важно заметить, что МОЕА в этом году начало программу "Добро пожаловать назад". В ее рамках предоставляются такие стимулы, как бесплатная аренда земли в течение первых двух лет, льготные банковские кредиты и доступ к налоговому консультированию (налоговый консалтинг-консультирование по вопросам исчисления и уплаты налогов, оптимизации налогообложения). По данным MOEA, 40 возвращающихся фирм создадут на местном рынке более 21,2 тыс. новых рабочих мест (то есть в среднем по 530 на фирму).

Представители каких групп возвращаются на остров? Это поставщики серверов, сетевых приборов, автомобильных компонентов, электроники транспортных средств, а также производители велосипедов. Во ІІ кв. этого года ожидается появление изготовителей прецизионных станков, а также представителей электронной промышленности.

Тайваньским фирмам становится все труднее оставаться в КНР из-за роста стоимости ведения бизнеса и ужесточения государственного контроля. Затраты на рабочую силу в Китае с 2009 года выросли в четыре раза, что сделало разницу в зарплатах в этих странах несущественной. Кроме того, правительство «Поднебесной» оказывает давление на фирмы с целью распределения расходов на социальное обеспечение, которые с 2009 года увеличились в три раза. И, наконец, китайские власти требуют уплаты 


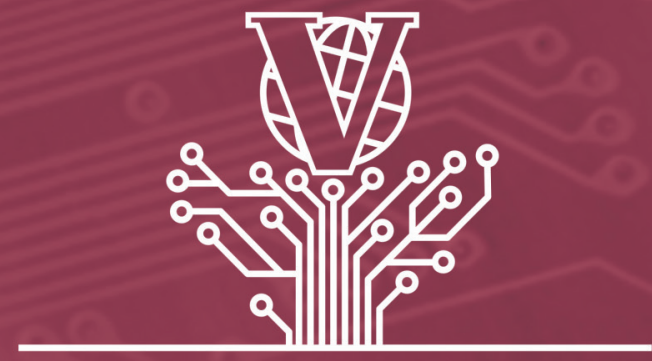

МЕЖДУНАРОДНЫЙ ФОРУМ

\section{МИКРОЭЛЕКТРОНИКА 2019}

30 сентября - 5 октября

Республика Крым,

г. Алушта

\section{V Юбилейный Международный Форум «Микроэлектроника 2019» -}

ключевое событие года в области микроэлектронных технологий

Научная конференция «ЭКБ и микроэлектронные модули»

v Деловая программа $\quad$ Демонстрационная зона

Фестиваль инноваций

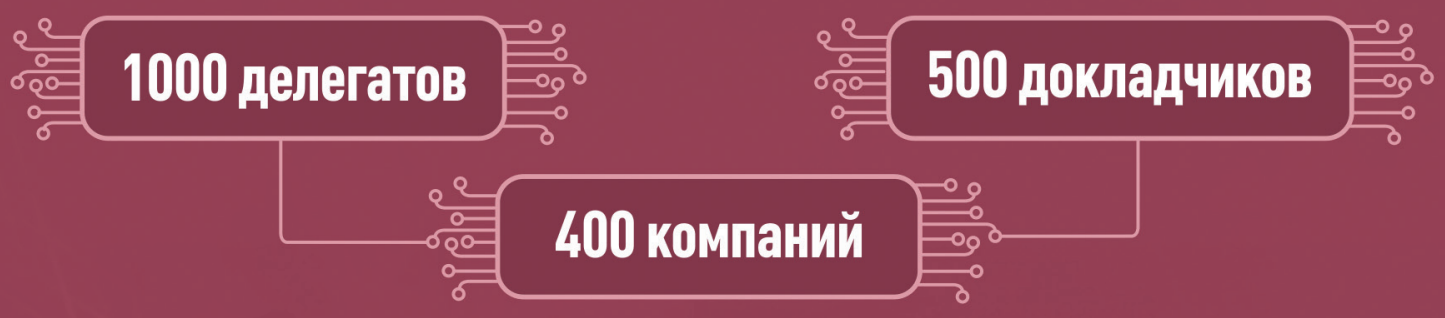

За все 4 года успешной работы

ПРИ ПОДДЕРЖКЕ

\section{1 МИНПРОМТОРГ \\ 1 РОссиИ}

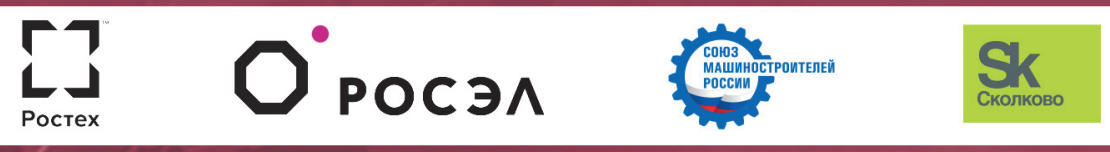

ОРГАНИЗАТОРЫ

Генеральный информационный партнёр

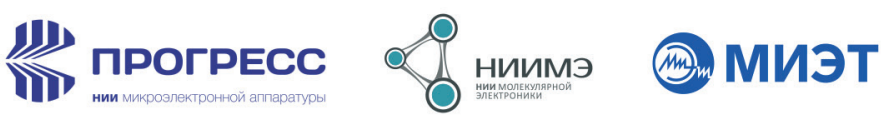

Операттор Форума: Компания «ПрофККонфреренции» — Тел.: +7 (495) 641-57-17 • E-mail: info@microelectronica.pro Подробная инфрормация и регистрация участников на официальном сайте Форума: microelectronica.pro 
экологических налогов. Все эти три фактора, вместе взятые, для многих фирм уже сделали ведение дел в Китае достаточно дорогим. Но дело не только в налогах - Пекин предъявляет все более назойливые требования, например, претендует на места в советах директоров для своих представителей. Например, соисполнитель и исполнительный председатель совета директоров корпорации Alibaba, одной из крупнейших фирм в области электронной коммерции, решил оставить свой пост вскоре после того, как Пекин и государственные предприятия начали играть все более активную роль в деятельности крупных корпораций. При председателе Си Цзиньпине серьезно выросли значение и размер национальной интернет-индустрии, что побудило власти "затянуть поводок». В настоящее время представители фирм, работающих в КНР, не рассматривают внезапную отставку человека как единичный случай. Они опасаются, что их бизнес также может столкнуться с усилением политического давления со стороны властей страны.

\section{Репатриация и дефицит электроэнергии}

Проблема, с которой может столкнуться правительство Тайваня, если все отечественные фирмы начнут массово возвращаться на остров, - дефицит электроэнергии. При значительном расширении производственных мощностей за счет возвращающихся производителей в условиях постепенного отказа от ядерной энергетики эта проблема неизбежно возникнет.

В течение последних нескольких лет правящая демократическая прогрессивная партия вела Тайвань к поставленной цели - достижение в 2025 году безъядерного статуса. Победившая на выборах во многих окружных магистратах и городах оппозиционная партия Гоминьдан требует более медленного снижения зависимости страны от ядерной энергетики.

Многое зависит от предстоящих в 2020 году президентских выборов, по итогам которых определится, какова будет политика «через пролив» - то есть смягчатся или обострятся отношения острова с материковым Китаем.

Для Тайваня, страны с относительно небольшим размером экономики, возвращение местных фирм из КНРважное событие. Это явление, безусловно, будет способствовать экономической модернизации острова.

Любопытно, что некоторые фирмы, возвращающиеся домой, желают остаться анонимными. Недавно MOЕА намекнуло, что инвестиции "известного" производителя электроники составят 54,7 млрд тайваньских долларов (1,77 млрд долл.). Это самая большая сумма капиталовложений среди 40 фирм, объявивших о своем возвращении на родину. Неназванная электронная фирма намерена создать 8 тыс. новых рабочих мест. Одним из основных направлений ее деятельности будет технология искусственного интеллекта [4].
На тайваньских производителей оказывает влияние американо-китайская торговая война. Например, тайваньская корпорация Foxconn, поставщик корпорации Apple, предупредила в середине июня о том, что она не только расширяет производство в США, но и готова увеличить производство знаковых iPhone за пределами Китая, если это будет необходимо [5].

$$
\therefore *
$$

В отличие от тайваньских фирм, южнокорейские производители микро- и радиоэлектроники занимают прочные позиции как на мировом, так и на китайском рынке. Хотя при создании новых зарубежных производств они, учитывая ухудшающиеся условия ведения бизнеса в КНР, все чаще открывают новые производства во Вьетнаме, в Таиланде и т.д. Учитывая разность экономических возможностей, положение тайваньских фирм по сравнению с китайскими конкурентами будет ухудшаться и дальше. В то же время дальнейшее развитие китайской микро- и радиоэлектроники будет во многом зависеть от успехов в деле разработки и приобретения передовых технологий и ряда других факторов. И, наконец, китайские производители радиоэлектроники стремятся обратиться к тайваньской цепочке поставок, поскольку они ищут альтернативные источники некоторых типов полупроводниковых приборов, чтобы минимизировать последствия тарифной войны с США и санкций в отношении Huawei [6]. Пойдут ли тайванцы на такое сотрудничество или примут сторону США, покажет время.

\section{ЛИТЕРАТУРА}

1. Макушин М. Микроэлектроника в Китае: новый этап развития // ЭЛЕКТРОНИКА: Наука, Технология, Бизнес. 2017. №7 (00168). С. 142-150.

2. Макушин М. КНР: новый этап развития микроэлектроники. Часть 2. Производственная база и зарубежная активность // ЭЛЕКТРОНИКА: Наука, Технология, Бизнес. 2017. №8 (00169). C. C. 142-151.

3. Luffy Liu. Countdown: How Close is China to $40 \%$ Chip SelfSufficiency? // EE Times China. 04.11.19.

4. https://www.eetimes.com/document.asp?doc_id=1334555\#

5. Junko Yoshida. Taiwan Tech Homeward Bound from China // EE Times. 04.28.19 https://www.eetimes.com/ document.asp?doc_id=1334623.

6. Lauly Li and Cheng Ting-Fang. Foxconn extends range of US plant as trade war divides tech market // Nikkei Asian Rewiev. June 11. 2019

7. https://asia.nikkei.com/Economy/Trade-war/Foxconnextends-range-of-US-plant-as-trade-war-divides-tech-market

8. Julian Ho, Willis Ke. China sees Taiwan supply chain as alternative to IDMs for power IC devices // Digitimes. Wednesday 19. June 2019.

9. https://www.digitimes.com/news/a20190619PD205.html 


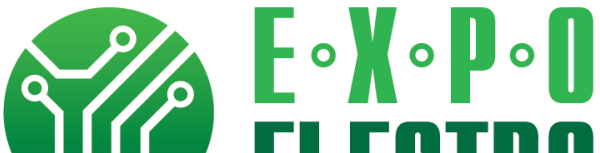 ELECTRONICA}

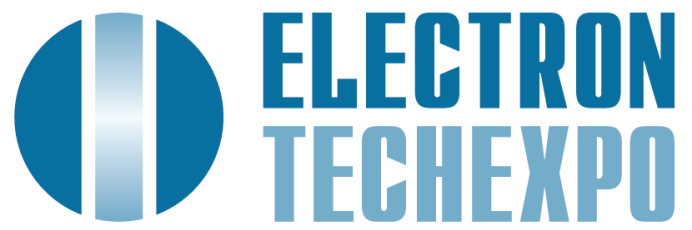

Выставки охватывают весь цикл производства электроники от производства микросхем до готовых изделий

$14-16$

апреля 2020

MockBa

Крокус Экспо
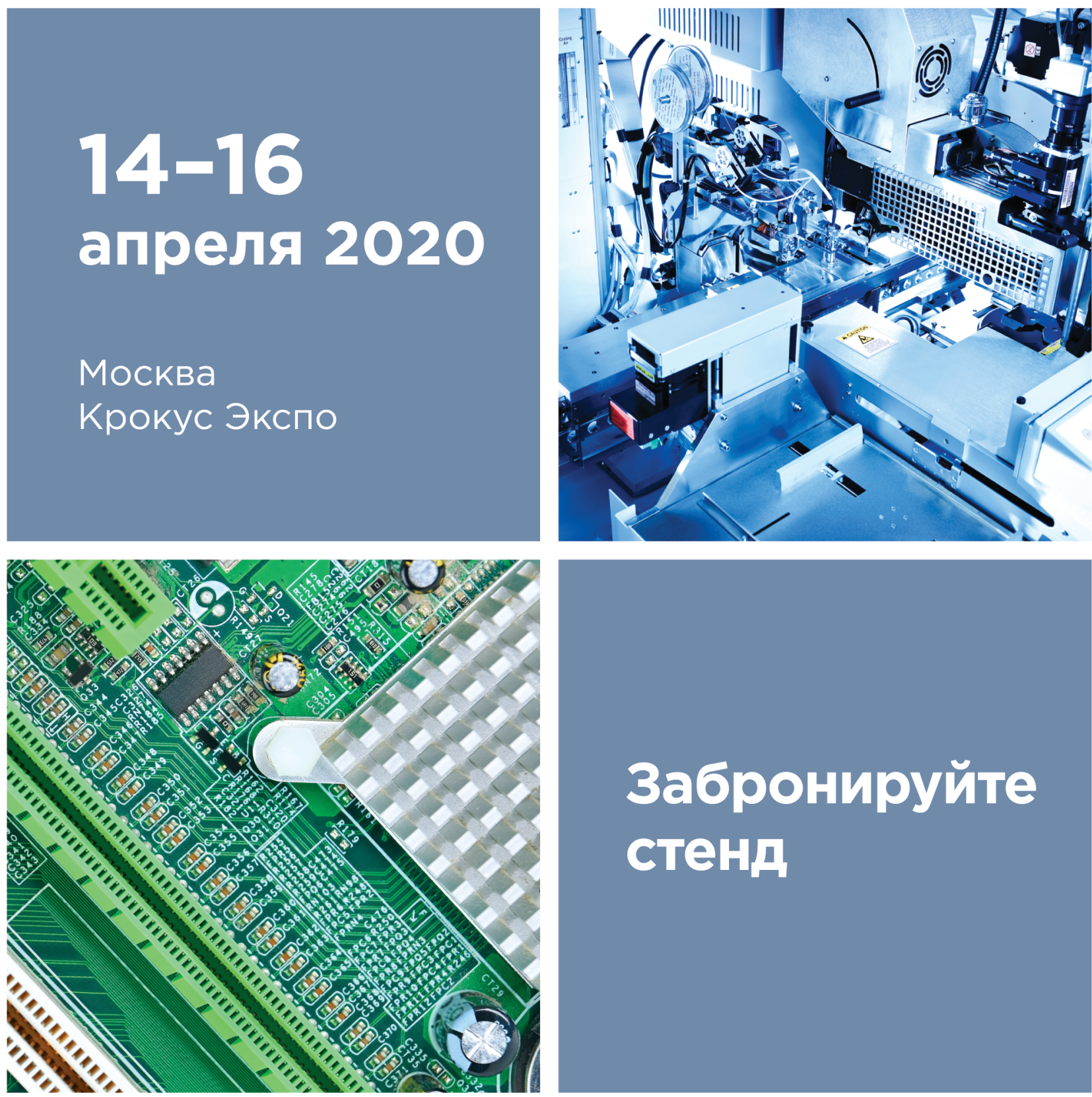

Забронируйте стенд

\section{Ваш компонент успеха!}

Организатор

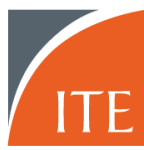




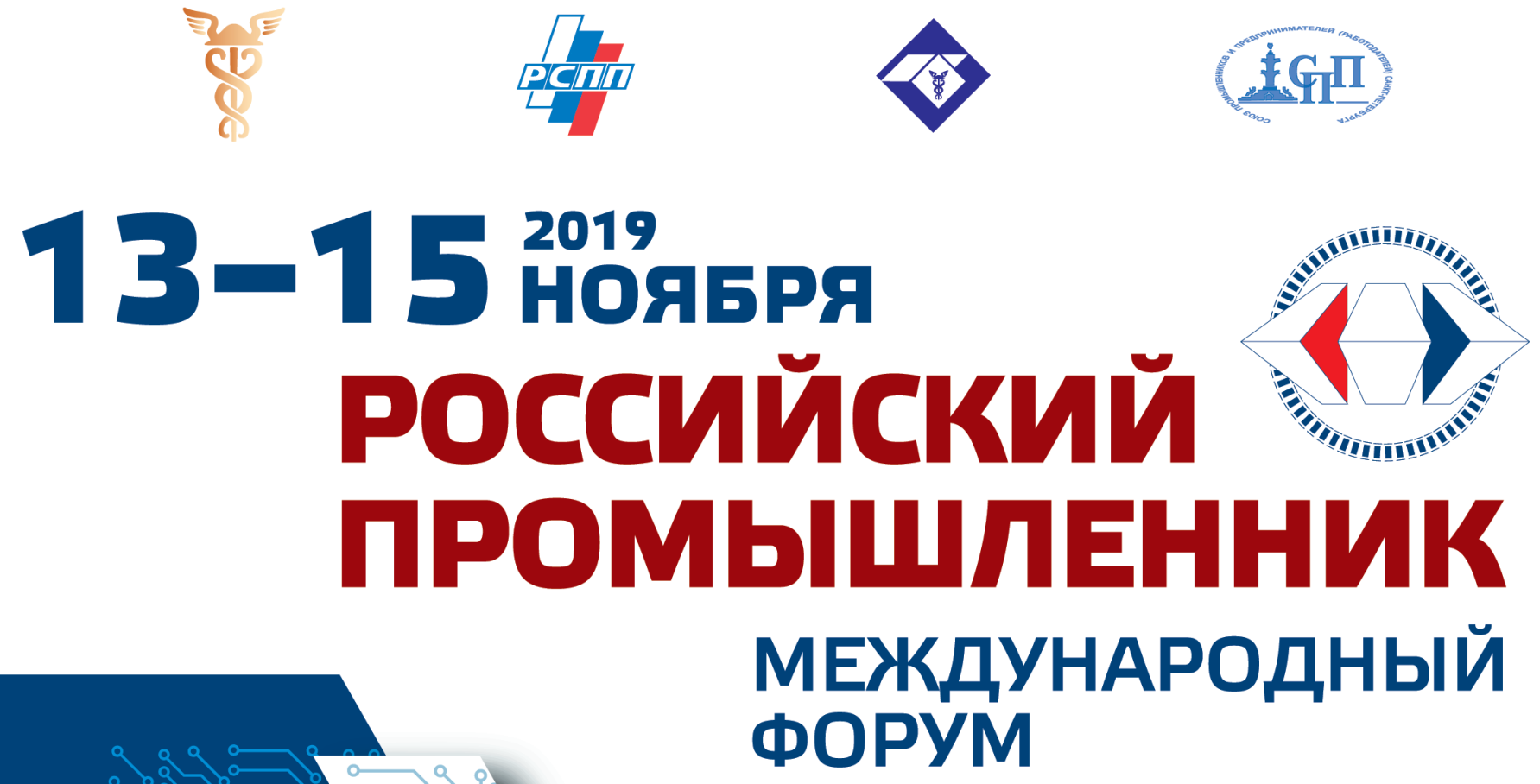

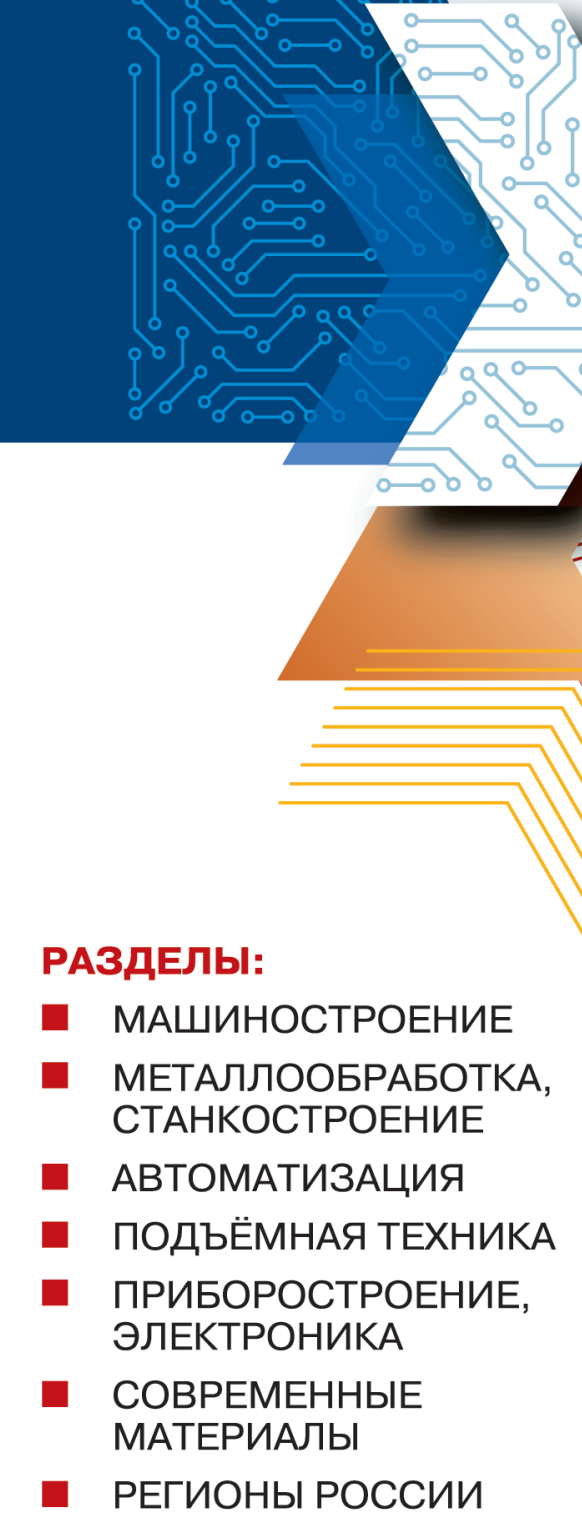

ОРГАНИЗАТОР
ОДНОВРЕМЕННО ПРОХОДЯТ:

D ПЕТЕРБУРГСКИЙ МЕЖДУНАРОДНЫЙ ИННОВАЦИОННЫЙ ФОРУМ

- ВЫСТАВКА-КОНГРЕСС “ЗАЩИТА ОТ КОРРОЗИИ»

ПАPTHËP

(TA3ПPOMБAHK
ГЕНЕРАЛЬНЫЙ МЕДИАПАРТНЁР

CAHKT-ПETEPEYPT 